Images in...

\title{
Isolated central nervous system relapse in a patient with diffuse large $B$ cell lymphoma
}

\author{
Kota Sato, Michihiro Uchiyama
}

Department of Haematology, Suwa Red Cross Hospital, Suwa, Japan

Correspondence to Dr Michihiro Uchiyama, mi.uchiyama@suwa.jrc.or.jp

\section{DESCRIPTION}

A 57-year-old woman was admitted to our hospital with headache, dizziness and nausea in August 2010. On admission, neurological examination revealed no significant abnormalities and the cranial nerves were also intact. Diffuse large B cell lymphoma of the liver was diagnosed in April 2006. The patient was treated with four cycles of rituximab-cyclophosphamide-doxorubicine-vincristine-predonisolone therapy and underwent extended left hepatic lobectomy following poor response to chemotherapy. Complete remission (CR) was subsequently achieved and positron emission tomography/CT performed in April 2010 confirmed CR. Brain MRI demonstrated a hyperintense area on T2-weighted imaging and this lesion showed gadolinium enhancement on T1-weighted imaging, about $20 \mathrm{~mm}$ in size, in the left cerebrum close to the fourth ventricle (figure 1). Biopsy was difficult to perform for this lesion. Examination of cerebrospinal fluid showed a white blood cell count of $49 / \mu 1$, a lactose dehydrogenase level of $52 \mathrm{IU} / \mathrm{l}$ and a total protein value of $98 \mathrm{mg} / \mathrm{dl}$. Cytology demonstrated slightly large lymphoid cells with a large nucleus/cytoplasmic ratio (figure 2), and these cells showed positive results for CD5, CD19, CD20, IgM and
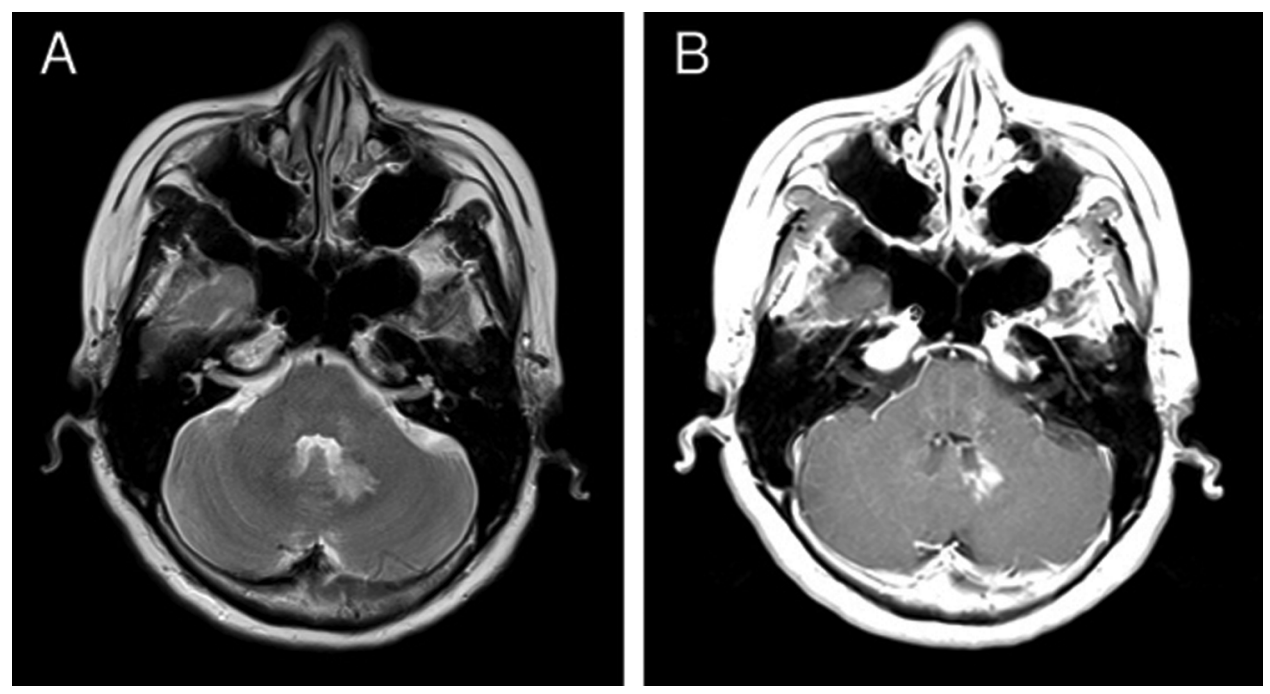

Figure 1 Brain MRI at diagnosis.

Patient consent Obtained. $\kappa$-chain on immunophenotyping analysis, compatible with the characteristics of the previously diagnosed lymphoma. These results led to a diagnosis of B cell lymphoma, probably representing isolated central nervous system (CNS) relapse, although biopsy had not been performed. The patient received methotrexate (MTX)-based chemotherapy (rituximab, MTX, procarbazine and vincristine) with the addition of whole-brain radiotherapy. ${ }^{1}$ Clinical manifestations improved immediately and CR was achieved after two cycles of the above regimen.

\section{Competing interests None.}

\section{REFERENCES}

1. Shah GD, Yahalom J, Correa DD, et al. Combined immunochemotherapy with reduced whole-brain radiotherapy for newly diagnosed primary CNS lymphoma. J Clin Oncol 2007;25:4730-5.

2. Doolittle ND, Abrey LE, Shenkier TN, et al. Brain parenchyma involvement as isolated central nervous system relapse of systemic non-Hodgkin lymphoma: an International Primary CNS Lymphoma Collaborative Group report. Blood 2008;111:1085-93.

3. Gleissner B, Chamberlain M. Treatment of CNS dissemination in systemic lymphoma. J Neurooncol 2007;84:107-17. 


\section{BMJ Case Reports}

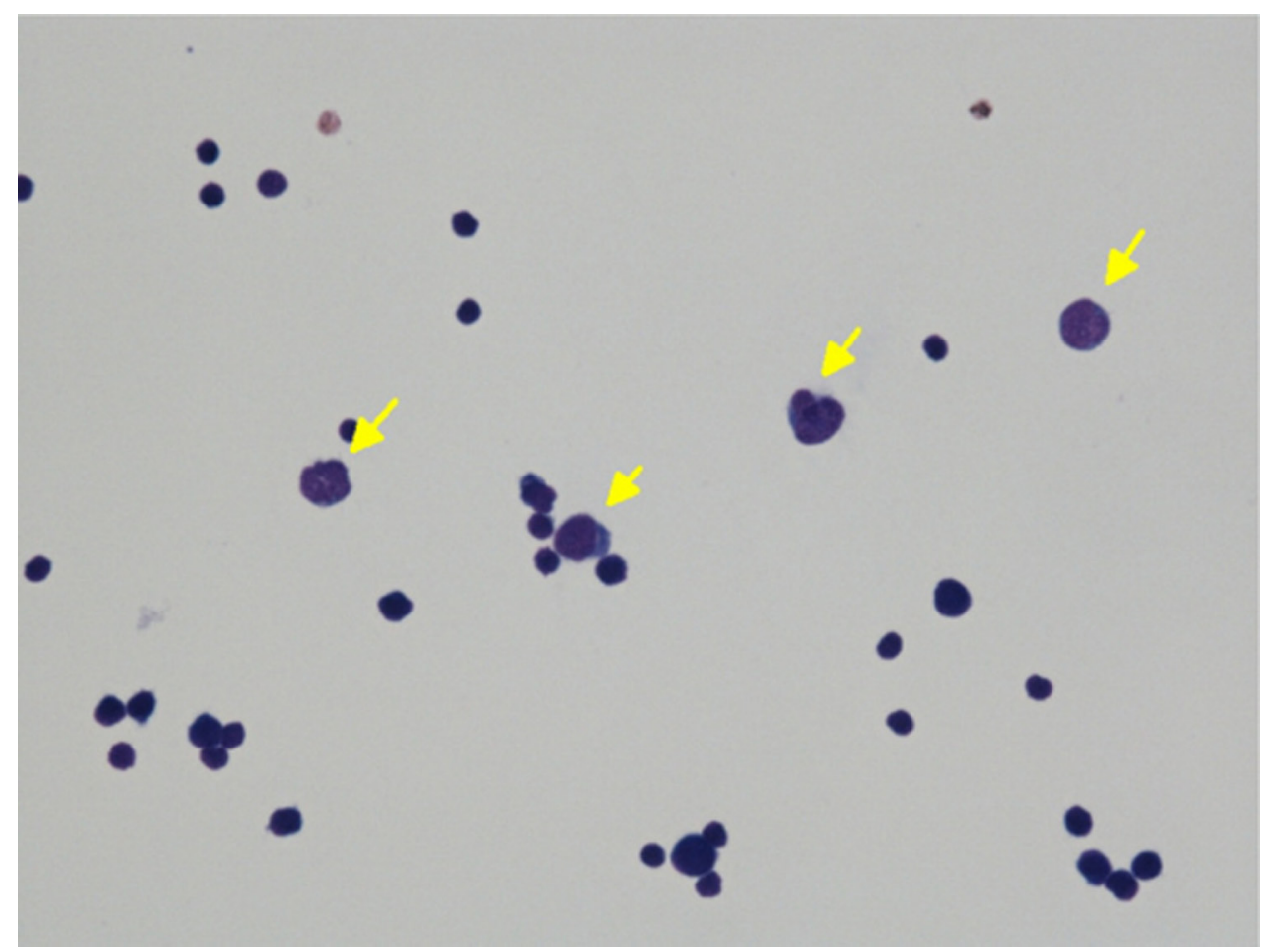

Figure 2 Cytological examination with Giemsa staining of cerebrospinal fluid at diagnosis.

This pdf has been created automatically from the final edited text and images.

Copyright 2012 BMJ Publishing Group. All rights reserved. For permission to reuse any of this content visit http://group.bmj.com/group/rights-licensing/permissions.

BMJ Case Report Fellows may re-use this article for personal use and teaching without any further permission.

Please cite this article as follows (you will need to access the article online to obtain the date of publication).

Sato K, Uchiyama M. Isolated central nervous system relapse in a patient with diffuse large B cell lymphoma. BMJ Case Reports 2012; 10.1136/bcr.12.2011.5275, Published XXX

Become a Fellow of BMJ Case Reports today and you can:

- Submit as many cases as you like

- Enjoy fast sympathetic peer review and rapid publication of accepted articles

- Access all the published articles

- Re-use any of the published material for personal use and teaching without further permission

For information on Institutional Fellowships contact consortiasales@bmjgroup.com

Visit casereports.bmj.com for more articles like this and to become a Fellow 